\title{
PENERAPAN METODE $V$-SHAPE LOADING UNTUK MENINGKATKAN PRODUKTIVITAS PC-2000 \& PC-1250 DI PIT 10 \& 11 MADHANI TALATAH NUSANTARA PT. ARUTMIN INDONESIA TAMBANG ASAMASAM
}

\author{
Enos $^{1}$, Kurnia Candra Utama ${ }^{1}$, Rahimatul Fadhilah ${ }^{2}$ \\ ${ }^{1} P T$. Arutmin Indonesia site Asamasam \\ ${ }^{2}$ PT. Madhani Talatah Nusantara
}

\begin{abstract}
ABSTRAK
Data produktivitas fleets overburden removal PT. Madhani Talatah Nusantara Asamasam Coal Project (ACP) Bulan Januari - Mei 2018 masih jauh di bawah target sehingga analisis untuk mengetahui akar permasalahan dan penyelesaiannya perlu dilakukan. Karakteristik material di ACP merupakan material free dig (no blasting \& no ripping), namun semakin dalamnya elevasi banyak terdapat area yang merupakan material keras. Pengambilan data awal dengan metode konvensional loading menunjukkan rendahnya produktivitas disebabkan karena lamanya loading time dan spotting time. Lamanya loading time diakibatkan digging rate yang tinggi, sedangkan lamanya spotting time disebabkan karena jauhnya manuver truk untuk memposisikan siap loading. Untuk mempertahankan efisiensi loading time excavator dan mempercepat waktu manuver truk diperlukan perubahan metode loading, yaitu metode $V$-shape loading.

Metode V-shape loading merupakan metode loading dimana posisi truk membentuk sudut "V" terhadap face penggalian. Penerapan metode $V$-shape loading memerlukan front kerja dengan luas minimal 20 meter untuk PC-2000 dan 15 meter untuk PC-1250. Metode V-shape loading bertujuan untuk mempercepat waktu manuver truk saat memposisikan siap loading, mengurangi swing radius excavator, dan mengurangi waktu angkat bucket excavator sehingga loading time semakin efisien dan produktivitas akan meningkat. Selain itu, metode ini juga mengurangi waktu delay perbaikan front loading oleh alat dorong dozer karena bekas front loading yang tidak dilalui oleh truk.

Metode $V$-shape loading tidak membutuhkan tambahan biaya untuk diterapkan, hanya diperlukan kepedulian pengawas dalam pengaturan di loading point. Sebelum penerapan metode ini, dilakukan sosialisasi untuk mendapatkan pemahaman dari semua pihak yang terlibat, terutama operator dan pengawas lapangan. Setelah itu, barulah dilakukan implementasi di lapangan dengan pengawasan yang ketat. Hasil penerapan dalam 5 bulan pengamatan menunjukkan adanya efisiensi loading time excavator dan manuver truk sehingga menghasilkan produktivitas yang meningkat. Pada PC2000, rata-rata produktivitas meningkat $107 \%$, dari sebelumnya $491 \mathrm{bcm} / \mathrm{jam}$ menjadi 527 $\mathrm{bcm} / \mathrm{jam}$. Sedangkan pada PC-1250, rata-rata produktivitas meningkat $145 \%$, dari sebelumnya 245 $\mathrm{bcm} / \mathrm{jam}$ menjadi $355 \mathrm{bcm} / \mathrm{jam}$.
\end{abstract}

Kata kunci : produktivitas, $V$-shape loading

\section{ABSTRACT}

Productivity data fleets overburden removal at PT. Madhani Talatah Nusantara Asamasam Coal Project (ACP) January - May 2019 was below target, so analysis for knowing the root of the problems and this solution is needed. Material characteristic at ACP is free dig material (no blasting \& no ripping), but there are much hard material in case of lower elevation. Conventional loading methods showed low productivity was caused by loading time \& spotting time above plan. Longer loading time was caused by longer digging rate, while longer spotting time was caused by longer truck positioning ready to load. For maintaining loading time efficiency \& maintaining spotting time, $V$-shape loading method is applied to change conventional loading method. 
$V$-shape loading method is loading method which truck position at " $V$ " angle to loading face. Application V-shape loading method needs large front loading minimal 20 meters for PC-2000 and 15 meters for PC-1250. The purpose of V-shape loading method is for speeding up spotting time for ready to load, reducing bucket excavator lifting time so efficiency loading time \& productivity increased. Moreover, this method is reducing delay front loading maintenance by dozer because truck spotting did not get through past loading point.

$V$-shape loading method did not need any cost for applying, just needed concern from foreman for observing at loading point. First, all foreman \& operator was given socialization for understanding how to apply this method. Then, $V$-shape loading applied with tight supervision. The result at 5 month application, there was efficiency loading time excavator \& spotting time excavator. For PC-2000, average productivity increased 107\%, from $492 \mathrm{bcm} / \mathrm{hrs}$ to $533 \mathrm{bcm} / \mathrm{hrs}$. Moreover, for PC-1250, average productivity increased $145 \%$ from $245 \mathrm{bcm} / \mathrm{hrs}$ to $355 \mathrm{bcm} / \mathrm{hrs}$.

Keywords : productivity, V-shape loading

\section{A. PENDAHULUAN}

\section{A.1. Latar Belakang}

PT Arutmin Indonesia merupakan salah satu perusahaan tambang batubara terbesar di Indonesia yang berlokasi di Kalimantan Selatan. Pada tahun 1981, PT Arutmin Indonesia dan Pemerintah menandatangani Perjanjian Karya Pengusahaan Pertambangan Batubara (PKP2B) generasi I No. J2/Ji.DU/45/81 dengan luas area penambangan 1.200.000 hektar. Tahap eksplorasi, studi kelayakan, dan konstruksi berlangsung pada tahun 1982-1989. Pada tahun 1990, tahap operasi produksi selama 30 tahun dengan wilayah seluas 70.153 hektar.

PT Arutmin Indonesia site Asamasam mulai berproduksi pada tahun 2004. Desa Asamasam, Kabupaten Tanah Laut, Provinsi Kalimantan Selatan. Lokasi secara geografis terletak di

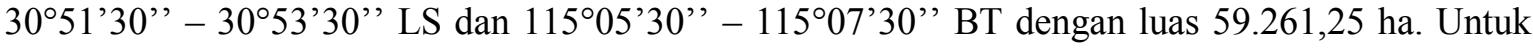
menuju tambang ini dapat menggunakan kendaraan roda dua maupun kendaraan roda empat melalui jalan darat dari kota Banjarbaru dengan jarak $\pm 100 \mathrm{~km}$ dan ditempuh kurang lebih selama 2,5 jam ke arah timur laut.

Di PT Arutmin Indonesia site Asamasam, kegiatan pengupasan batuan penutup dikerjakan oleh kontraktor tunggal yaitu PT Darma Henwa. Kemudian, PT Darma Henwa memiliki subkontraktor untuk mengerjakan sebagian pit, yaitu PT Madhani Talatah Nusantara (MTN). PT Madhani Talata Nusantara memiliki populasi 4 unit PC 2000, 1 unit Liebherr 9200, dan 2 unit PC 1250 untuk mengerjakan Pit $9-11$.

Pengupasan batuan penutup merupakan salah satu kegiatan pokok dari pertambangan sesuai kaidah good mining practice. Pengupasan batuan penutup di site Asamasam dilakukan secara langsung (free dig), karena formasi batuan yang sebagian besar merupakan pasiran atau lempung. Namun, karena semakin dalamnya elevasi penggalian, maka batuan keras (hard material) juga semakin banyak ditemukan.

Keberhasilan pengupasan batuan penutup menjadi sangat vital karena inventori batubara tergantung dari langkah ini. Keberhasilan tersebut dalam pertambangan sering disebut dengan produksi, yaitu jumlah batuan penutup yang dipindahkan dari loading point (pit) ke disposal (outpit). Sedangkan, kriteria keberhasilan produksi salah satunya ditentukan oleh produktivitas, yaitu produksi per satuan waktu kerja (bcm/jam).

Dari data production report fleets MTN pada Bulan Januari - Mei 2018 di dapatkan bahwa produktivitas PC 2000 masih jauh di bawah target, yaitu $492 \mathrm{bcm} /$ jam atau 80\% dari target yang 
ditetapkan $608 \mathrm{bcm} / \mathrm{jam}$. Sedangkan untuk PC 1250 MTN pada bulan yang sama hanya 245 $\mathrm{bcm} / \mathrm{jam}$ atau $60 \%$ dari target yang ditetapkan $408 \mathrm{bcm} / \mathrm{jam}$. Dari data tersebut, analisis untuk mengetahui akar permasalah penyebab rendahnya produktivitas dan penyelesaiannya perlu dilakukan untuk dapat meningkatkan produksi pada pengupasan batuan penutup di Madhani Talatah Nusantara PT Arutmin Indonesia tambang Asamasam.

\section{A.2. Tujuan}

Adapun tujuan penelitian ini adalah sebagai berikut:

1) Mengidentifikasi faktor-faktor spesifik (site based) yang mempengaruhi produktivitas excavator PC 2000 \& PC 1250 MTN

2) Melakukan perubahan metode konvensional loading menjadi $V$-shape loading untuk meningkatkan produktivitas PC 2000 \& PC 1250 MTN

\section{A.3. Pendekatan Pemecahan Masalah}

Penelitian ini dimulai dari identifikasi masalah yaitu berupa pengumpulan data sebelum dilakukan improvement (metode konvensional loading), kemudian dilakukan analisis faktor sebab akibat secara spesifik dan site based menggunakan fishbone diagram. Setelah itu, dilakukan penyusunan rencana perbaikan metode loading berdasarkan faktor-faktor yang ada. Setelah didapatkan bahwa metode $V$-shape loading merupakan metode yang dapat diterapkan, kemudian disusun hand out penerapan metode $V$-shape loading, karena metode ini merupakan metode loading baru di site, sehingga perlu dilakukan sosialisasi kepada semua pihak yang terlibat untuk mendapatkan pemahaman yang komprehensif dan menghindari kejadian yang tidak diinginkan akibat ketidakpahaman salah satu pihak (faktor safety). Setelah itu barulah dilakukan implementasi di lapangan dengan pengawasan ketat. Evaluasi hasil perbiakan dengan metode $V$-shape loading kemudian dianalisis dan dibandingkan dengan metode konvensional. Berikut merupakan flow chart penelitian ini:

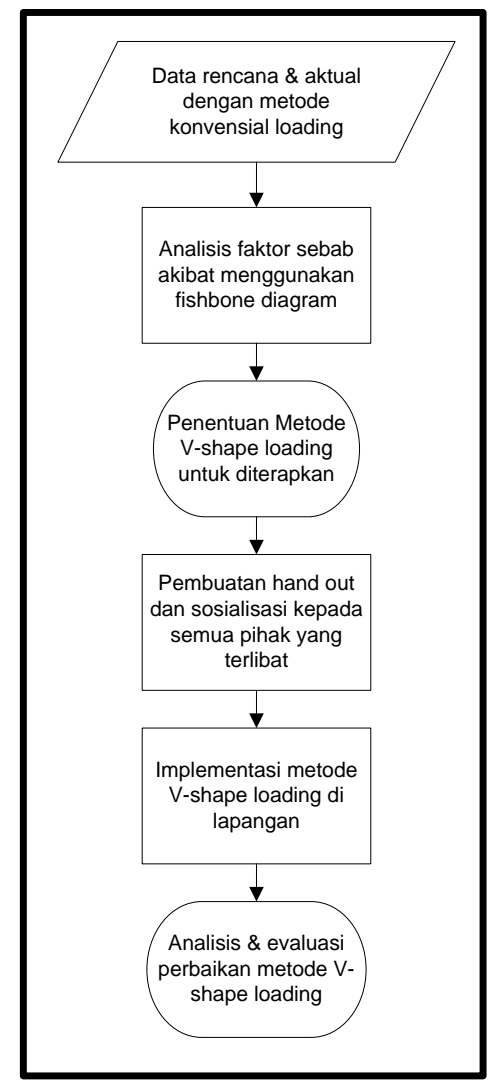

Gambar 1. Flow Chart Penelitian 


\section{A.4. Batasan Masalah}

Batasan masalah yang diteliti dalam penelitian ini adalah sebagai berikut:

1) Penelitian dilakukan di Pit 10 dan 11 PT Arutmin Indonesia site Asamasam yang dikerjakan oleh subkontraktor PT Madhani Talatah Nusantara

2) Penelitian dilakukan pada PC 2000 atau sekelasnya, dan PC 1250

\section{B. TEORI DASAR}

\section{B.1. Fishbone Diagram}

Fishbone diagram (diagram tulang ikan-karena bentuknya seperti tulang ikan) sering juga disebut Cause-and-Effect Diagram atau Ishikawa Diagram diperkenalkan oleh Dr. Kaoru Ishikawa, seorang ahli pengendalian kualitas dari Jepang, sebagai satu dari tujuh alat kualitas dasar (7 basic quality tools). Fishbone diagram digunakan ketika kita ingin mengidentifikasi kemungkinan penyebab masalah dan terutama ketika sebuah team cenderung jatuh berpikir pada rutinitas.

Suatu tindakan dan langkah improvement akan lebih mudah dilakukan jika masalah dan akar penyebab masalah sudah ditemukan. Manfaat fishbone diagram ini dapat menolong kita untuk menemukan akar penyebab masalah secara user friendly. Fishbone diagram akan mengidentifikasi berbagai sebab potensial dari satu efek atau masalah, dan menganalisis masalah tersebut melalui sesi brainstorming. Masalah akan dipecah menjadi sejumlah kategori yang berkaitan, mencakup manusia, material, mesin, prosedur, kebijakan, dan sebagainya. Gambar 2 menunjukkan ilustrasi fishbone diagram.

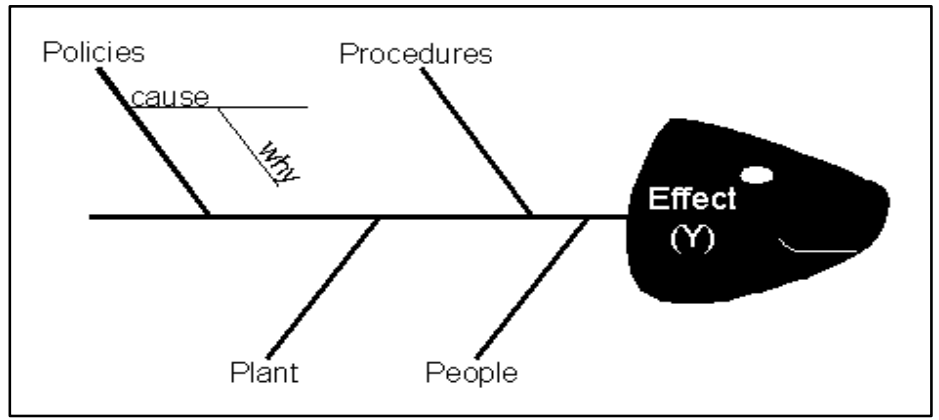

Gambar 2. Fishbone Diagram

\section{B.2. Produktivitas \& Cycle Time}

Produktivitas dapat didefinisikan sebagai banyaknya material yang dapat digali serta dimuat oleh sebuah excavator dalam satuan waktu tertentu. Produktivitas merupakan suatu ukuran penilaian terhadap kinerja dari excavator.

Menurut komatsu sebagai pabrik pembuat alat berat memberikan cara menghitung perkiraan produktivitas excavator tersendiri dengan persamaan:

$$
\text { Produktivitas }=\frac{60}{T} \cdot B C \cdot F k \cdot B F
$$

Keterangan:

$\mathrm{T}=$ cycle time (menit)

$\mathrm{BC}=$ Kapasitas bucket $(\mathrm{m} 3)$

$\mathrm{Fk}=$ Kondisi manajemen dan medan kerja

$\mathrm{BF}=$ Faktor pengisian bucket

Sedangkan, persamaan produktivitas secara praktikal di lapangan yaitu: 


$$
\text { Produktivitas }(B C M / h r)=\frac{\text { Units Moved }}{\text { Hours time }}
$$

Sedangkan, cycle time excavator adalah waktu yang dibutuhkan untuk satu kali rangkaian pengisian material ke dump truck, persamaan cycle time yaitu:

$$
\mathrm{T}=\mathrm{t} 1+\mathrm{t} 2+\mathrm{t} 3+\mathrm{t} 4
$$

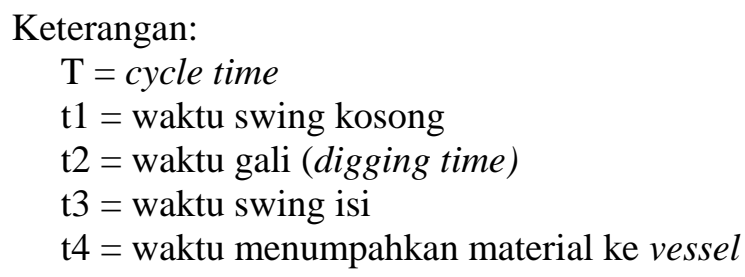

\section{B. METODOLOGI PENELITIAN}

\section{B.1. Identifikasi \& Analisis Masalah}

Seperti penjelasan pada metode penelitian pada bab sebelumnya, identifikasi dan analisis awal diperlukan untuk menemukan akar masalah penyebab rendahnya produktivitas. Dari hasil perhitungan, Gambar 3 dan Gambar 4 menunjukkar review produktivitas berdasarkan data production report Bulan Januari - Mei 2018:

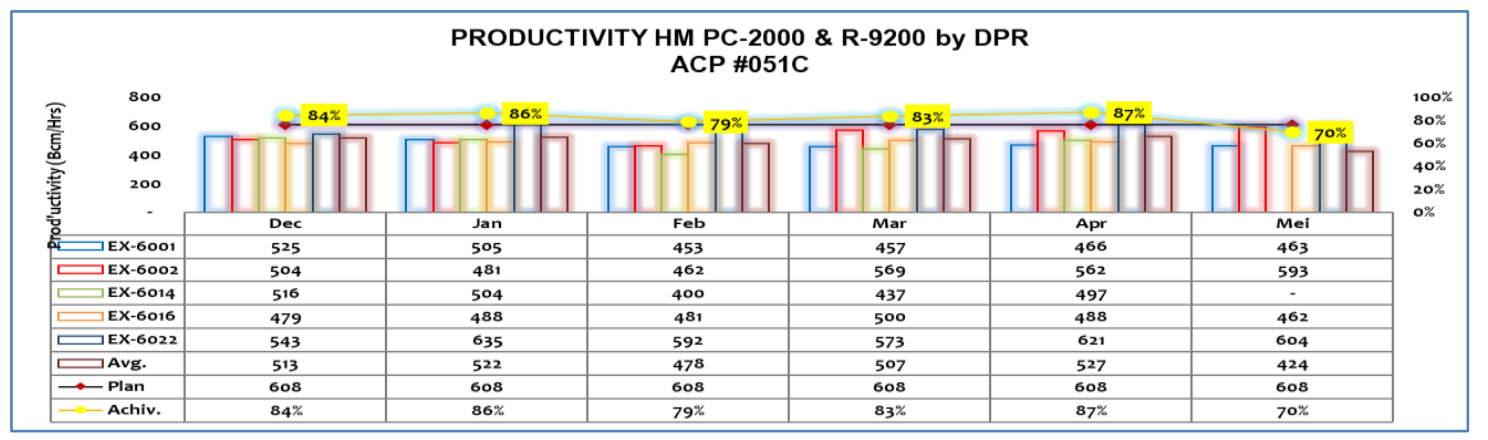

Gambar 3. Tabel \& Grafik Produktivitas PC 2000 dengan Metode Loading Konvensional

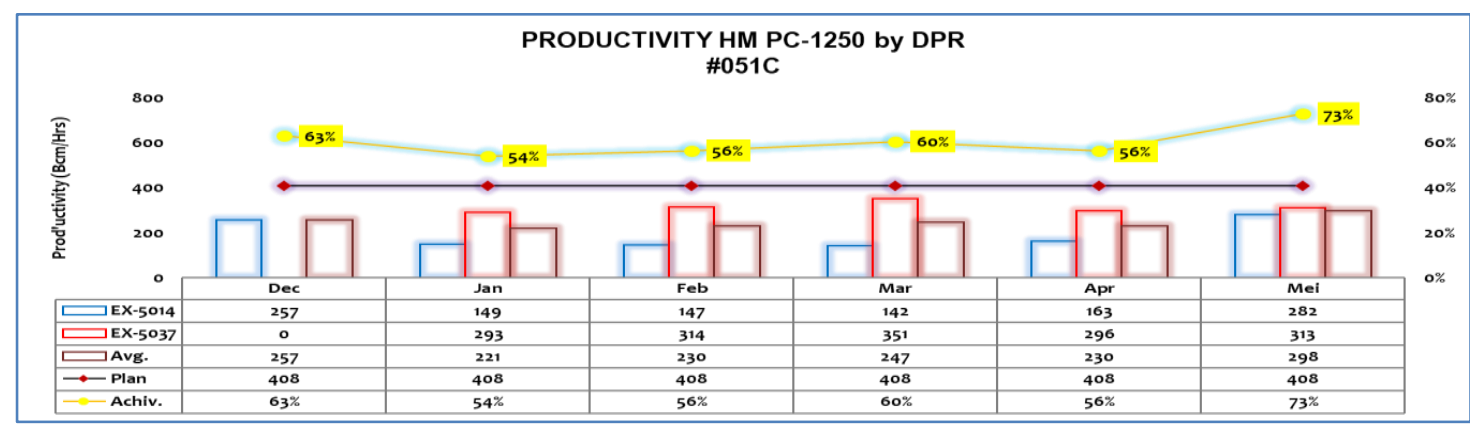

Gambar 4. Tabel \& Grafik Produkivitas PC 1250 dengan Metode Loading Konvensional

Dari kedua tabel dan grafik di atas, terlihat bahwa produktivitas excavator PC 2000 masih 82\% dan PC 1250 dengan metode loading konvensional masih jauh di bawah target. 


\section{B.2. Analisis Sebab Akibat}

Analisis sebab akibat bertujuan untuk menemukan penyebab utama rendahnya produktivitas excavator secara site spesifik. Dari hasil pengamatan, fishbone diagram sebab akibat ditunjukkan dalam Gambar 5 sebagai berikut:

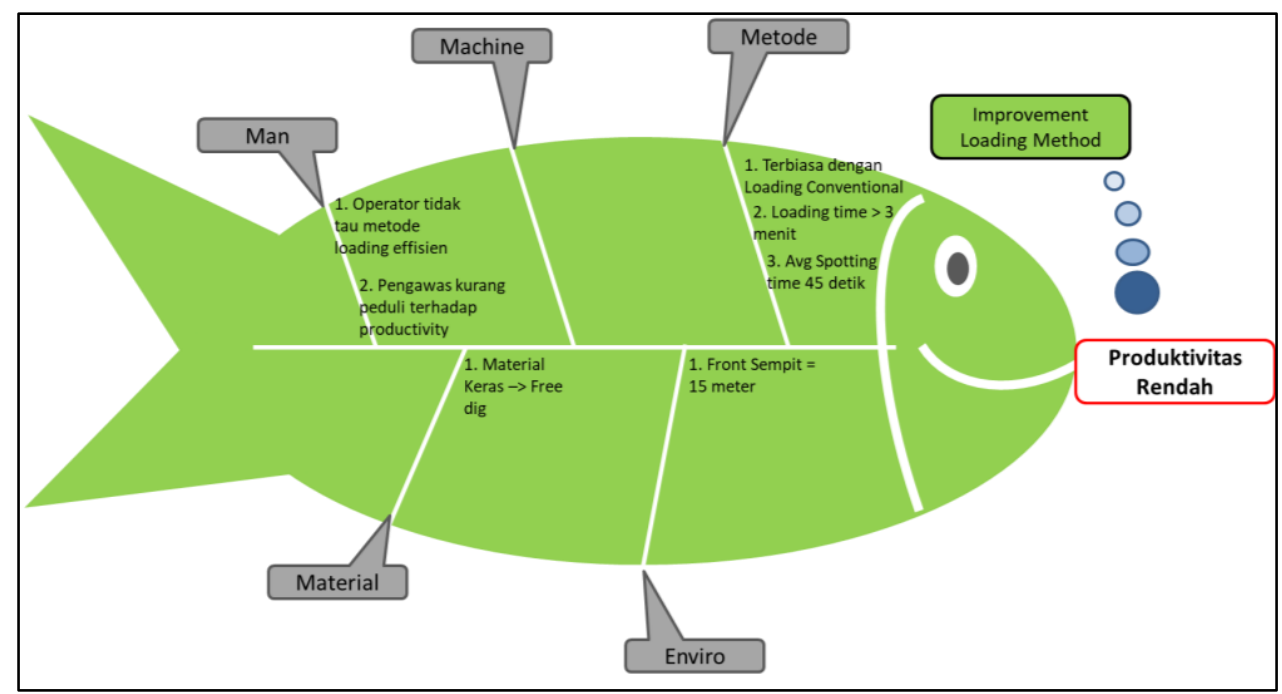

Gambar 5. Fishbone Diagram

Faktor Manusia :

1) Operator tidak mengetahui metode loading yang efisien

2) Pengawas yang kurang peduli terhadap pencapaian produktivitas

Faktor Metode :

1) Terbiasa dengan metode konvensional loading

2) Loading time lebih dari 3 menit

3) Tidak ada efisiensi pada spotting time, spotting time lebih dari 45 detik

Faktor Material

- Material keras yang di loading dengan free dig (digging time lambat)

Faktor Lingkungan

- Front sempit kurang dari 15 meter

\section{B.3. Metode V-shape Loading}

Penerapan metode $V$-shape loading diperlukan pemahaman yang komprehensif, terutama dari pihak-pihak yang terlibat, yaitu operator excavator, operator HD, dan pengawas loading point. Berikut adalah langkah-langkah penerapan metode $V$-shape loading:

1) Persiapan Front Loading

- Pertahankan face penggalian tegak lurus dan bersih

- Pembersihan front diupayakan tidak mengganggu manuver truk

- Pertahankan ketinggian dudukan excavator 4 meter

2) Manuver di Front

- Posisi vessel samping mengarah lurus dengan posisi front idler excavator

- Posisi parkir truk membentuk sudut V terhadap face penggalian, dan tidak menutup posisi penggalian terdekat excavator

- Operator excavator wajib mengupayakan posisi bucket tidak mengganggu manuver dan parkir truk 
- HD melakukan manuver dan memposisikan siap loading tanpa menunggu bucket excavator menggantung

- HD antri berjarak 1x dari HD yang sedang mengisi, dengan posisi sudah siap manuver

3) Loading

- Ketika HD melakukan manuver, excavator mulai menggali material dari area terjauh dari HD agar manuver truk tidak terganggu, lanjutkan menggali dari posisi terdekat HD hingga terjauh, agar menjaga swing isi dan kosong tetap pada jarak yang sama

- Lakukan dumping isi di vessel dari depan ke belakang

Gambar 6 menunjukkan ilustrasi langkah-langkah metode loading V-shape dari persiapan front loading, manuver di front, dan loading.

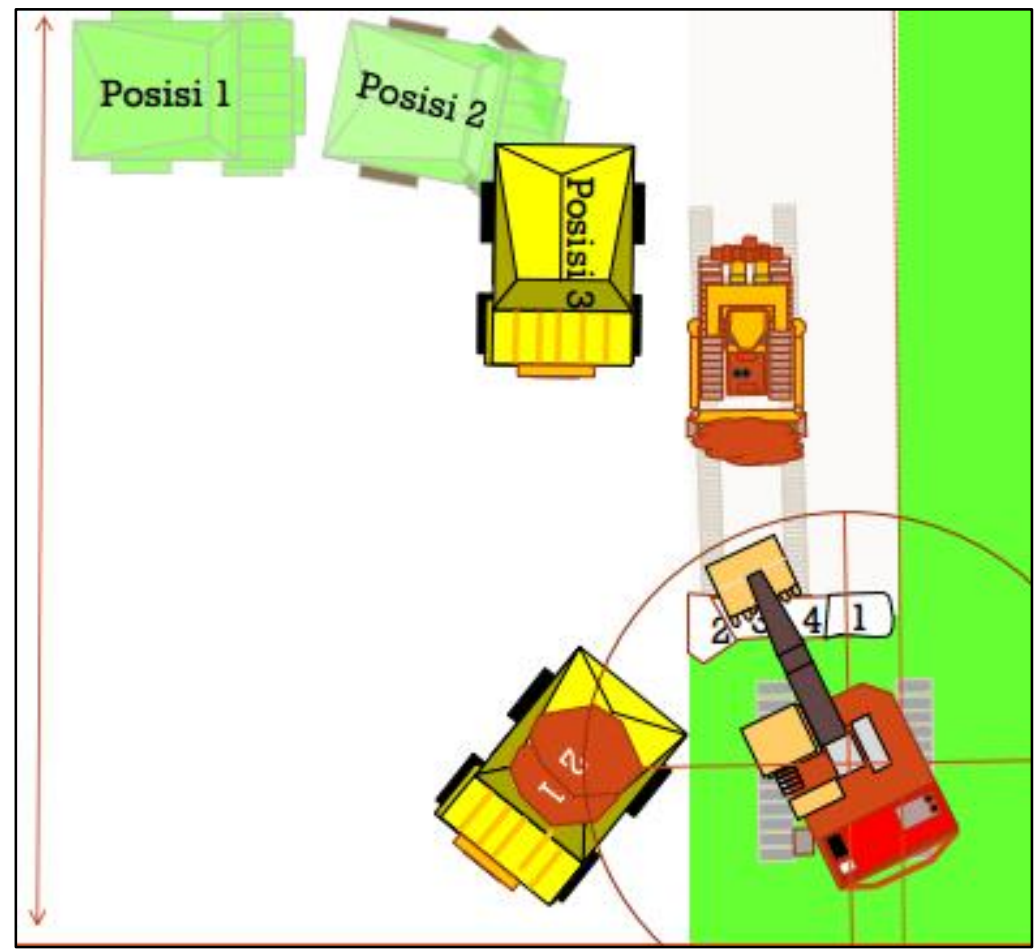

Gambar 6. Ilustrasi Metode V-shape Loading

\section{B.4. Sosialisasi Metode Loading}

Metode ini merupakan metode baru, sehingga pemahaman oleh semua pihak yang terlibat sangat penting. Sebelum diadakan penerapan di lapangan, sosialisasi di kelas dan di lapangan dilakukan. Sosialisasi dilaksanakan secara bergantian, dari mulai mine superintendent, supervisor, foreman, dan tentunya operator baik excavator, HD maupun dozer, yang terlibat aktif dalam penerapan nantinya. Gambar 7 dan Gambar 8 menunjukkan kegiatan sosialisasi metode loading baik di kantor maupun di lapangan sebelum diterapkan, dan tabel 1 menunjukkan persentase karyawan terlibat yang tersosialisasikan metode $V$-shape loading ini. 


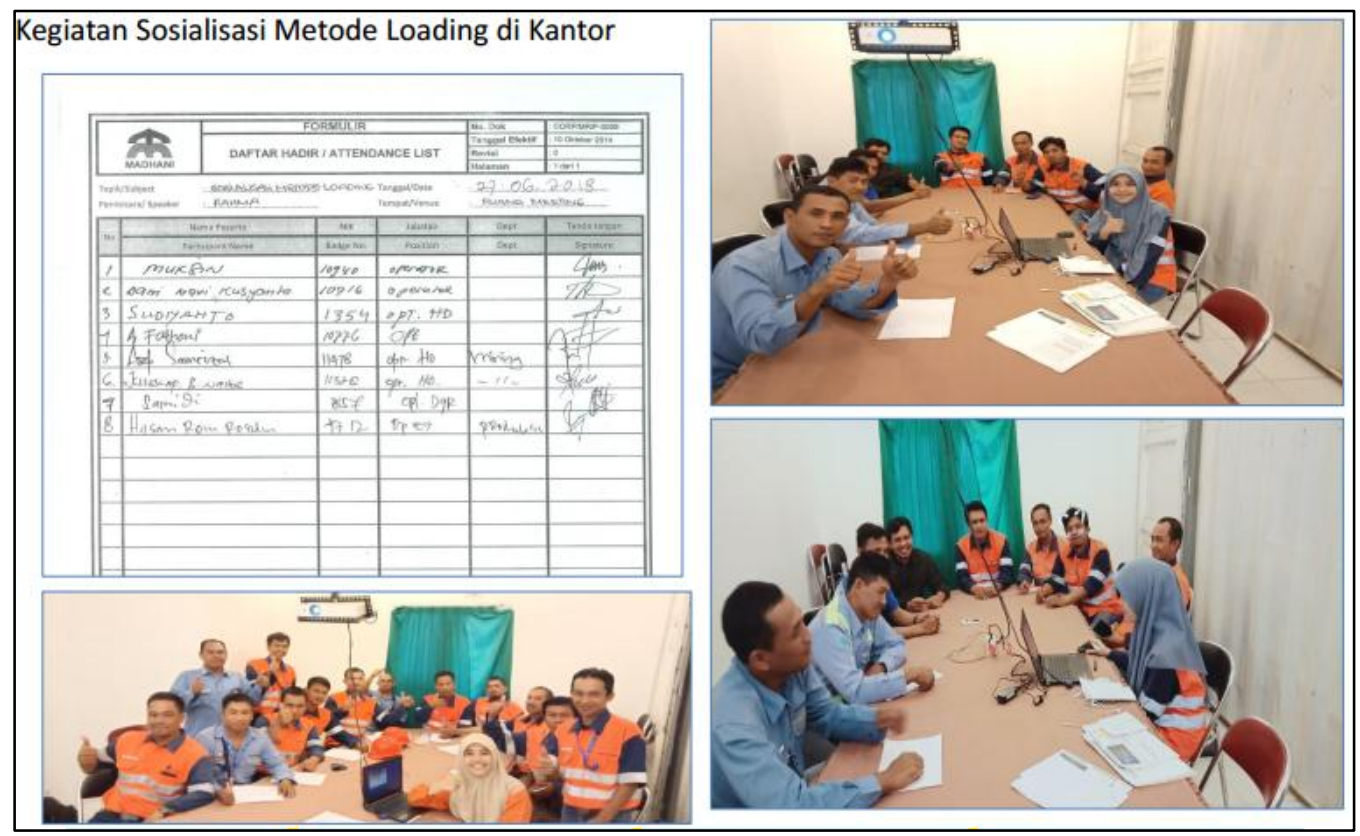

Gambar 7. Sosialisasi Metode V-Shape Loading di Kantor MTN

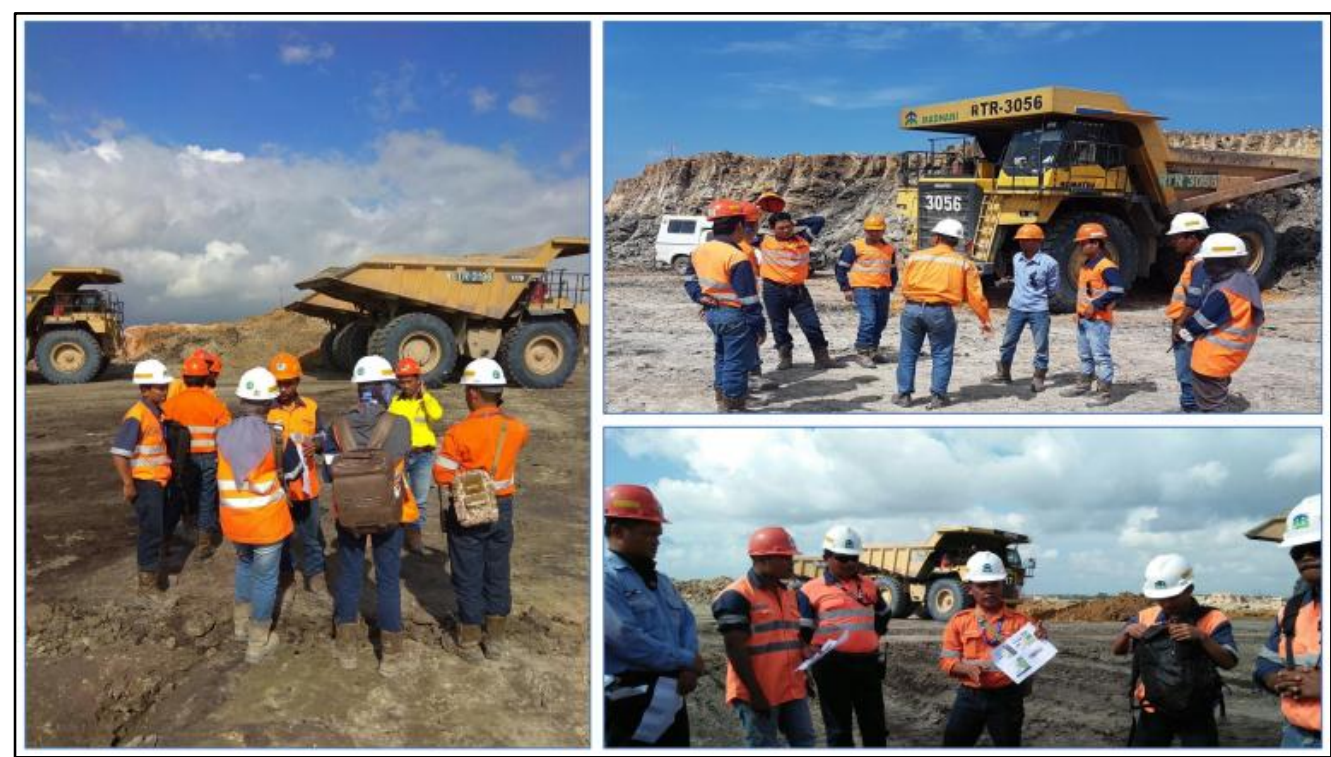

Gambar 8. Sosialisasi Metode V-Shape Loading di Lapangan sebelum Penerapan

Tabel 1. Pensentase Karyawan Terlibat yang Tersosialisasikan

\begin{tabular}{|cccccc|}
\hline \multirow{2}{*}{ No } & \multirow{2}{*}{ Item } & Man & \multicolumn{2}{c|}{ Sosialisasi } & \multirow{2}{*}{ \%tage } \\
\cline { 4 - 6 } & & Power Act & Sudah & Belum & \\
\hline 1 & Mine Supt & 1 & 1 & 0 & $100 \%$ \\
2 & Mine Spv & 4 & 1 & 3 & $\square$ \\
3 & Mine Foreman & 13 & 11 & 2 & $85 \%$ \\
4 & HD \& OHT & 71 & 58 & 13 & $82 \%$ \\
5 & Bulldozer & 16 & 8 & 8 & $50 \%$ \\
\hline 6 & Excavator & 30 & 18 & 12 & $60 \%$ \\
7 & Trainer & 5 & 5 & 0 & $100 \%$ \\
8 & Total & $\mathbf{1 4 0}$ & $\mathbf{1 0 2}$ & $\mathbf{3 8}$ & $\mathbf{7 3 \%}$ \\
\hline
\end{tabular}




\section{HASIL DAN PEMBAHASAN}

Metode $V$-shape loading adalah metode penggalian dimana dimana posisi truk membentuk sudut "V" terhadap face penggalian. Penerapan metode $V$-shape loading memerlukan front kerja dengan luas minimal 20 meter untuk PC-2000 dan 15 meter untuk PC-1250. Metode V-shape loading bertujuan untuk mempercepat waktu manuver truk saat memposisikan siap loading, mengurangi swing radius excavator, dan mengurangi waktu angkat bucket excavator sehingga loading time semakin efisien dan produktivitas akan meningkat. Selain itu, metode ini juga mengurangi waktu delay perbaikan front loading oleh alat dorong dozer karena bekas front loading yang tidak dilalui oleh HD. Gambar 9 menunjukkan penerapan metode $V$-shape loading di lapangan.

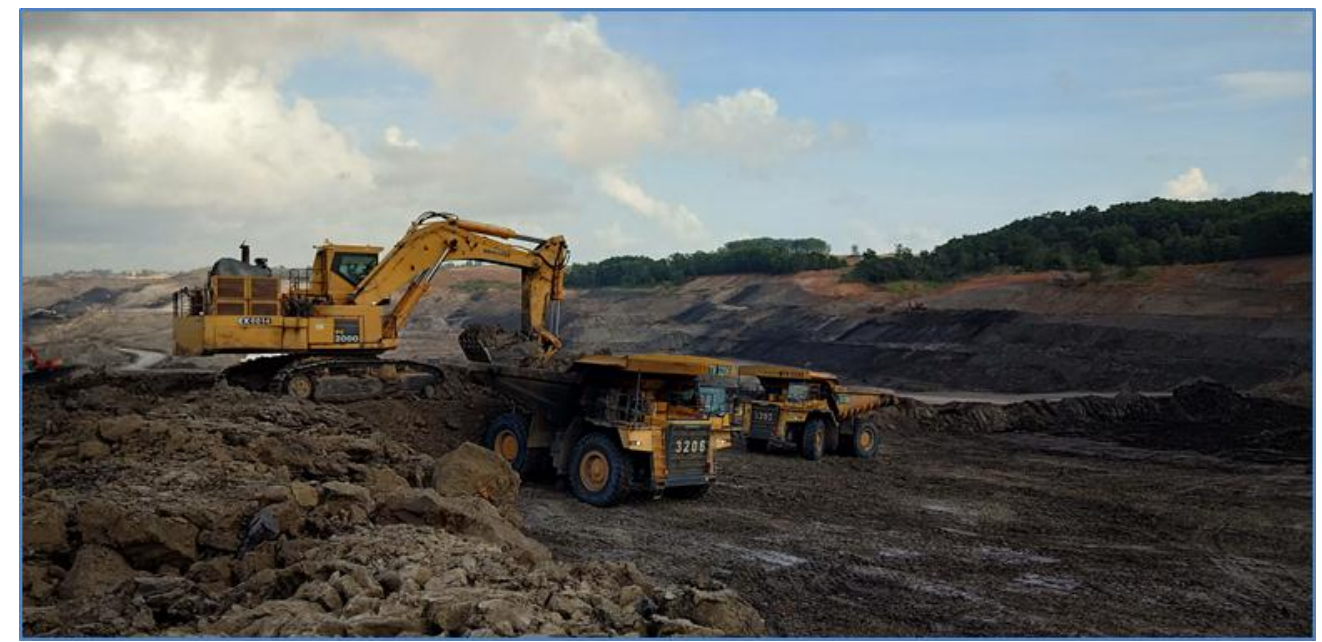

Gambar 9. Implementasi V-shape Loading

Tabel 2. Perbandingan Penerapan V-shape Loading terhadap Konvensional Loading

\begin{tabular}{|c|c|c|c|c|c|c|c|c|c|}
\hline \multicolumn{5}{|l|}{ EX-6001 } & \multicolumn{5}{|l|}{ EX-6002 } \\
\hline Date & : & 30-Jan-18 & 24-Jul-18 & & Date & : & 25 -Jan-18 & 25-Jul-18 & \\
\hline Time & : & $08.00-10.00$ & $09.00-10.00$ & & Time & : & $15.00-17.00$ & $09.00-10.00$ & \\
\hline Operator & $:$ & Budi Santoso & Purwanto & & Operator & : & Welem Rerung & Hasan Rosidin & \\
\hline Foreman & : & Yakobus & Togar T Sitinjak & & Foreman & : & Yakobus & Beni Markus & \\
\hline Supervisor & : & Baharudin & Taufik Rahmanto & & Supervisor & : & Baharudin & Taufik Rahmanto & \\
\hline Material & : & $\mathrm{OB}$ & $\mathrm{OB}$ & & Material & : & $\mathrm{OB}$ & $\mathrm{OB}$ & \\
\hline Bench Height & : & 3 & 4 & meter & Bench Height & : & 4 & 3.5 & meter \\
\hline Bench Width & : & 20 & 30 & meter & Bench Width & : & 15 & 15 & meter \\
\hline Distance & & 2000 & 2110 & meter & Distance & : & 1700 & 2050 & meter \\
\hline Pit & : & & 11 & & Pit & : & 4 & 9 & 9 \\
\hline Disposal & : & Basuki & Void 12 & & Disposal & : & IPD & IPD & \\
\hline Loading Method & : & Bench Loading & Bench Loading & & Loading Method & : & Bench Loading & Bench Loading & \\
\hline Study Motion & Units & $\begin{array}{c}\text { Before V- } \\
\text { Shape }\end{array}$ & After V-Shape & Variance & Study Motion & Units & $\begin{array}{c}\text { Before V- } \\
\text { Shape }\end{array}$ & After V-Shape & Variance \\
\hline Digging & $\sec$ & 19.9 & 23.5 & -3.6 & Digging & $\sec$ & 18.9 & 18.1 & 0.8 \\
\hline Swing Loaded & $\sec$ & 7.2 & 6.3 & 0.9 & Swing Loaded & $\sec$ & 11.4 & 6.2 & 5.3 \\
\hline Dump & $\sec$ & 4.9 & 3.4 & 1.4 & Dump & $\mathrm{sec}$ & 4.3 & 3.6 & 0.7 \\
\hline Swing Empty & $\sec$ & 7.9 & 5.6 & 2.4 & Swing Empty & $\mathrm{sec}$ & 5.1 & 5.4 & -0.3 \\
\hline Cycle Time & $\sec$ & 39.9 & 38.7 & 1.2 & Cycle Time & $\sec$ & 39.7 & 33.3 & 6.4 \\
\hline Bucket/Truck & & 6.0 & 6.7 & -0.7 & Bucket/Truck & & 5.3 & 6.9 & -1.6 \\
\hline Load Time & $\min$ & 4.0 & 4.3 & -0.3 & Load Time & $\min$ & 3.5 & 3.8 & -0.3 \\
\hline Jumlah Bucket & $n$ & 6.0 & 6.7 & -0.7 & Jumlah Bucket & $n$ & 5.3 & 6.9 & -1.6 \\
\hline BFF & $\%$ & $80 \%$ & $66 \%$ & $-14 \%$ & BFF & $\%$ & $95 \%$ & $63 \%$ & $-32 \%$ \\
\hline Job Efficiency & $\%$ & $75 \%$ & $89 \%$ & $14 \%$ & Job Efficiency & $\%$ & $69 \%$ & $93 \%$ & $24 \%$ \\
\hline Productivity by Obs & bcm/hrs & 450.0 & 497.0 & 47.0 & Productivity by Obs & bcm/hrs & 475.0 & 579.0 & 104.00 \\
\hline Productivity by PPC & bem/hrs & 560.0 & 585.0 & 25.0 & Productivity by PPC & $\mathrm{bcm} / \mathrm{hrs}$ & 380.0 & 535.0 & 155.0 \\
\hline Cycle Time Truck & $\min$ & 20.2 & 19.2 & 1.0 & Cycle Time Truck & $\min$ & 19.0 & 20.8 & -1.8 \\
\hline Exchange truk & $\sec$ & 83.76 & 53.5 & 30.26 & Exchange truk & $\mathrm{sec}$ & 100.57 & 43.6 & 56.97 \\
\hline Spotting time & $\sec$ & 56.92 & 35.5 & 21.42 & Spotting time & $\mathrm{sec}$ & 52.33 & 30.8 & 21.53 \\
\hline
\end{tabular}

Dari hasil tabel tersebut, penerapan metode $V$-shape loading sangat berpengaruh pada naiknya job efisiensi yang signifikan. Hal ini disebabkan dua faktor yang paling berpengaruh yaitu waktu exchange truck (pergantian truk), atau ketika truk datang ke front loading sampai waktu manuver 
berkurang 54\% dari metode konvensional loading. Selain itu, yang berpengaruh adalah spotting time yang menjadi sangat efektif, yaitu $61 \%$ dari waktu spotting daripada menggunakan metode konvensional loading. Peningkatan pada match factor tentunya akan menaikan nilai produktivitas, dari tabel 2 terlihat produktivitas meningkat signifikan.

Penerapan metode ini dalam jangka waktu yang singkat tentunya tidak komprehensif dibandingkan dengan metode konvensional yang biasa dilakukan di ACP. Kesinambungan atau kontinuitas penerapan metode ini menjadi tantangan tersendiri, terutama bagi pengawas dan operator yang terlibat langsung. Peran keduanya sangat penting dalam rencana peningkatan produktivitas fleets Madhani Talatah Nusantara. Tabel 3 dan Tabel 4 menunjukkan peningkatan produktivitas dalam 6 bulan penerapan metode $V$-shape loading.

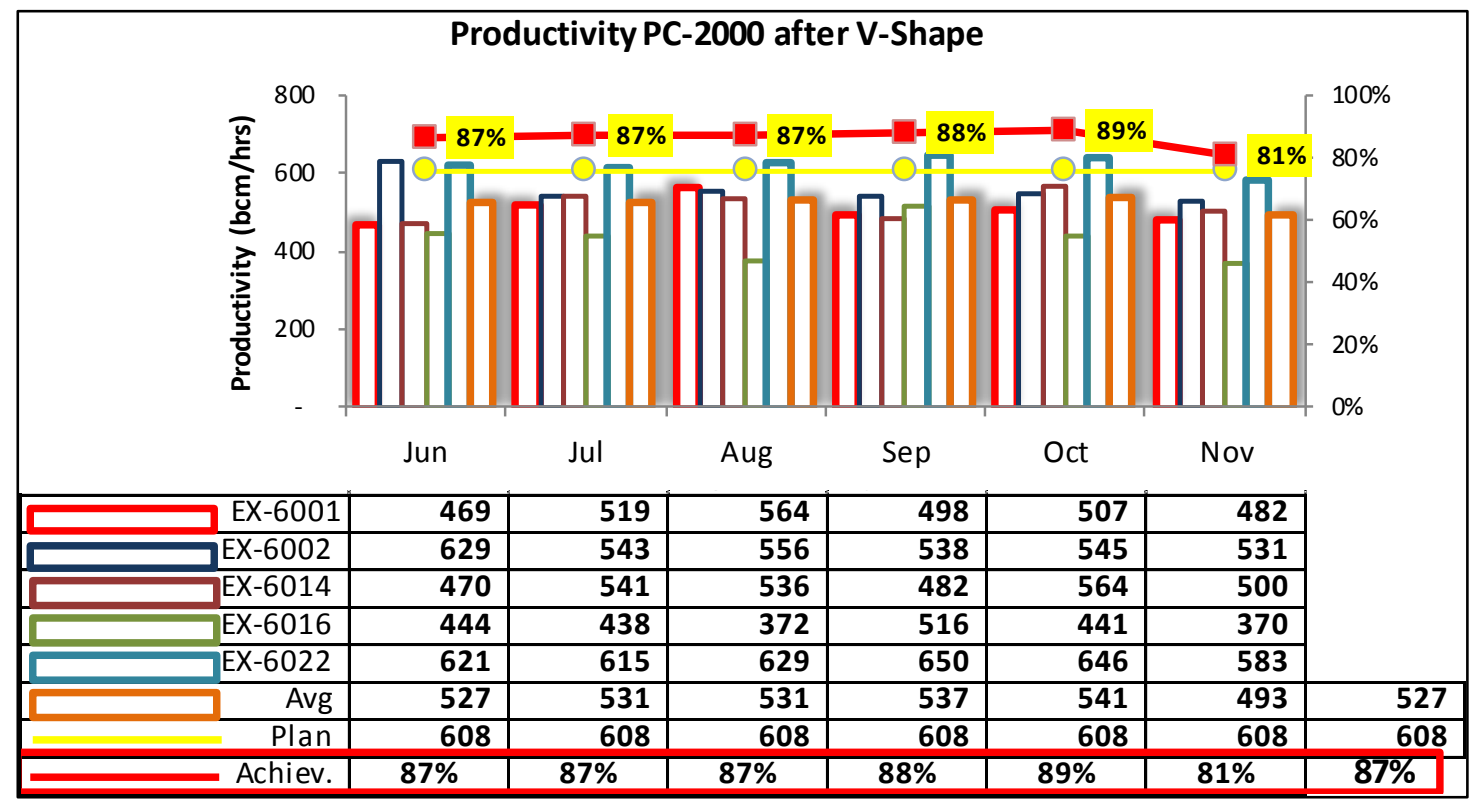

Gambar 10. Produktivitas PC-2000 setelah Penerapan V-Shape Loading

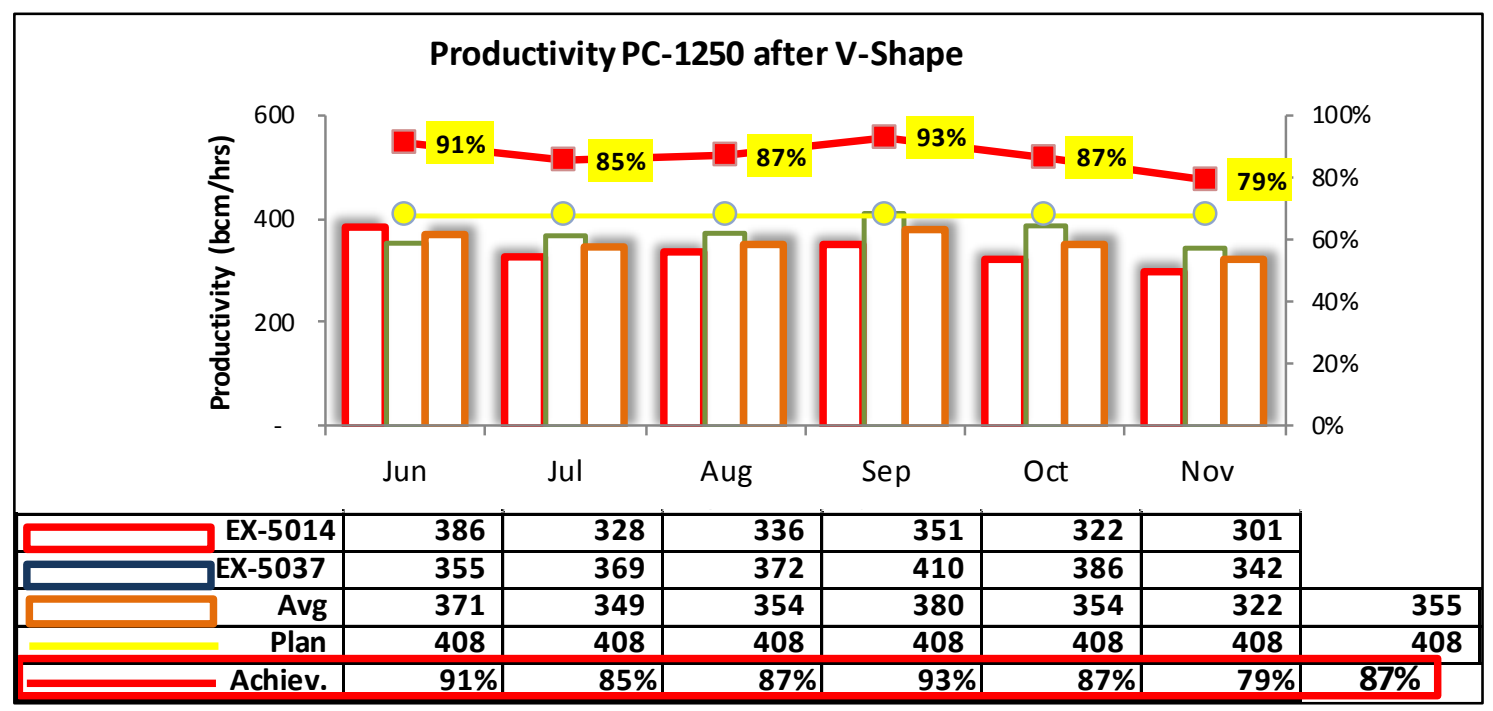

Gambar 11. Produktivitas PC-1250 setelah Penerapan V-Shape Loading

Dari kedua tabel \& grafik di atas terlihat bahwa produktivitas meningkat dalam 6 bulan penerapan metode $V$-shape loading di Madhani Talatah Nusantara ACP, dimana dengan metode konvensional untuk bulan Januari - Mei 2018 produktivitas PC-2000 sebesar 492 bcm/jam naik menjadi 527 bcm/jam atau mengalami kenaikan sebesar $107 \%$ periode Juni - Desember 2019. Dalam periode 
waktu yang sama, untuk PC-1250 dari sebelumnya $245 \mathrm{bcm} / \mathrm{jam}$ naik menjadi $355 \mathrm{bcm} / \mathrm{jam}$ atau mengalami kenaikan $145 \%$.

\section{KESIMPULAN}

1) Faktor penyebab rendahnya produktivitas yaitu digging rate excavator tinggi dengan metode konvensional, menyebabkan cycle time lebih tinggi dari plan.

2) Karakteristik material di ACP yaitu free dig (material keras), sehingga digging time tinggi. Metode $V$-shape loading yang memperkecil spotting time \& swing time menjadi solusi untuk meningkatkan produktivitas untuk tetap mempertahankan loading time.

3) Kenaikan produktivitas sebesar 107\% dari $492 \mathrm{bcm} / \mathrm{jam}$ menjadi $527 \mathrm{bcm} / \mathrm{jam}$ untuk PC2000 dan sebesar $145 \%$ dari $355 \mathrm{bcm} / \mathrm{jam}$ menjadi $355 \mathrm{bcm} / \mathrm{jam}$ setelah penerapan metode $V$-shape loading di ACP dalam jangka waktu 6 bulan penerapannya.

\section{DAFTAR PUSTAKA}

Andini, A.N., 2009. Analisis Waktu Tunggu Truk di Area Penambangan Pit J PT Kaltim Prima Coal. Bandung: Institut Teknologi Bandung.

Fishbone Diagram dan Langkah-Langkah Pembuatannya, diperoleh dari situs intenet https://eriskusnadi.com/2011/12/24/fishbone-diagram-dan-langkah-langkah-pembuatannya/ pada 14 September 2019

Sulistianto, B., 2008. Diktat TA2221 Peralatan Tambang dam Penanganan Material, Bandung: Lembaga Afiliasi Penelitian dan Industri Institut Teknologi Bandung. Ltd. , 2013, Komatsu Specifications and Application Handbook, Edition 31. Komatsu 
PROSIDING TPT XXVIII PERHAPI 2019 